LBNL-47300

\title{
Public Goods and Private Interests: Understanding Non-Residential Demand for Green Power
}

\author{
Ryan H. Wiser and Meredith Fowlie \\ Lawrence Berkeley National Laboratory \\ 1 Cyclotron Rd., MS 90-4000 \\ Berkeley, California 94720
}

\section{Edward A. Holt}

Ed Holt \& Associates, Inc.

28 Headland Road

Harpswell, Maine 04079

January, 2001 
Public Goods and Private Interests: Understanding Non-Residential Demand for Green Power 


\section{Table of Contents}

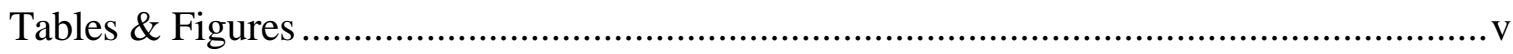

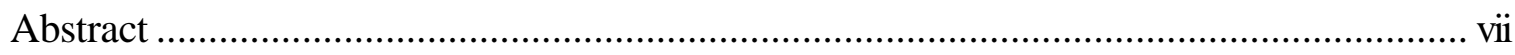

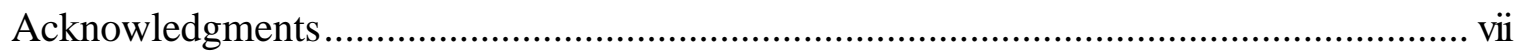

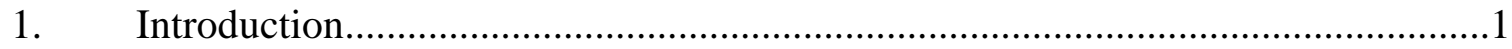

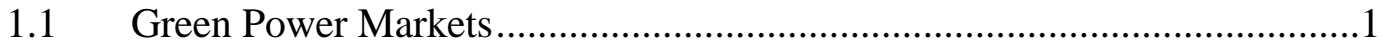

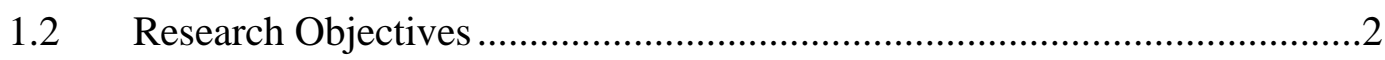

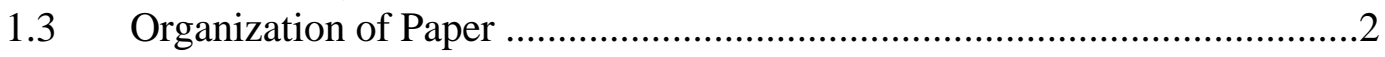

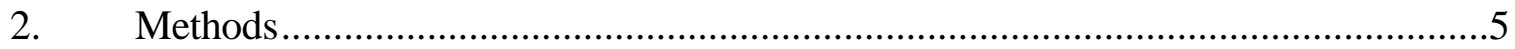

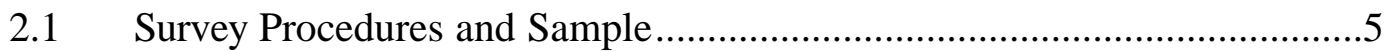

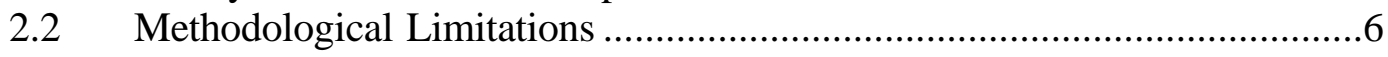

3. Buying Green Power: Survey Results ..................................................

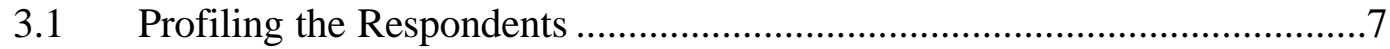

3.2 Green Power Premiums ................................................................... 8

3.3 The Green Power Procurement Process....................................................8

3.4 The Champion for Green Power .............................................................. 10

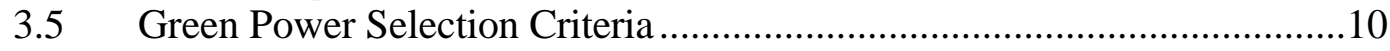

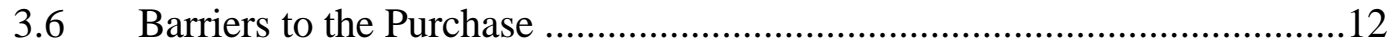

3.7 Customer Satisfaction ................................................................... 13

4. Motivations for and Benefits of the Green Power Purchase ...............................15

4.1 Voluntary Environmental Initiatives: Why Participate? ..........................15

4.2 Motivations for Green Power Purchases: Survey Results .......................17

$4.3 \quad$ Factor Analysis ................................................................................. 18

4.4 Extracting Public Image and Green Marketing Value ..............................19

4.5 Bandwagon and First Mover Strategies ...........................................21

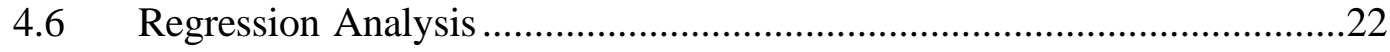

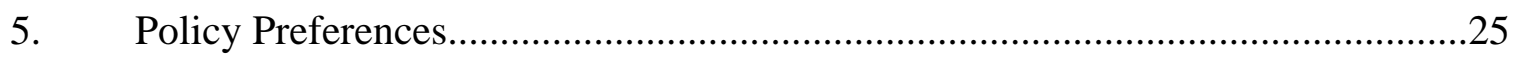

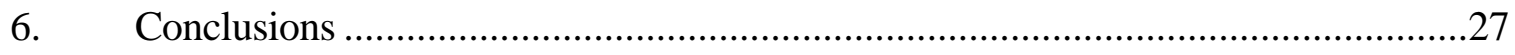

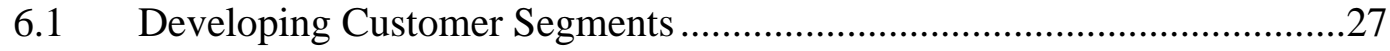

6.2 Understanding Customer Motivations .............................................27

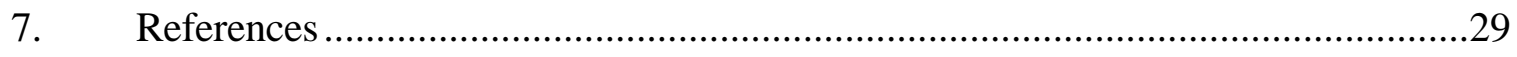

Appendix A: "Survey for Customers of Competitive Marketers"

Appendix B: "Survey for Customers of Regulated Utilities" 
Public Goods and Private Interests: Understanding Non-Residential Demand for Green Power 


\section{List of Tables and Figures}

Table 1 Survey Response Rates .6

Table 2 Champion of Green Power by Organization Size

Table 3 Rating of Various Supplier Selection Criteria (mean response on 5-point scale) 11

Table 4 Rating of Various Product Selection Criteria (mean response on 5-point scale) 11

Table 5 Barriers to Purchasing Green Power (mean response on 5-point scale) .............12

Table 6 Motivations for Purchasing Green Power ......................................................17

Table 7 Motivating Green Power Purchasers..............................................................17

Table 8 Factor Loadings and Explained Variances.................................................18

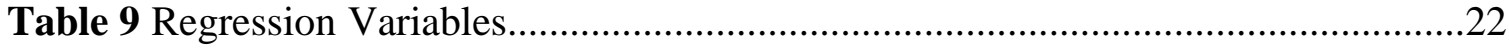

Table 10 Standardized Regression Coefficients....................................................23

Figure 1 Who Takes the Initiative in Pursuing a Green Power Purchase? .......................9

Figure 2 Getting the Word out About Green Power ................................................20

Figure 3 Secondary Marketing Efforts by Private Value Index Category.......................21 
Public Goods and Private Interests: Understanding Non-Residential Demand for Green Power 


\begin{abstract}
This article presents the results of the first large-scale mail survey of non-residential green power customers in the United States. The survey explored the motivations, attitudes, and experiences of 464 business, non-profit, and public-sector customers that have voluntarily opted to purchase - and frequently pay a premium for - renewable electricity. Results of this study should be of value to marketers interested in targeting these customer segments, to policymakers interested in fostering and understanding non-residential demand for green power, and to academics pondering the motivations for firms to engage in such voluntary environmental initiatives.
\end{abstract}

\title{
Acknowledgements
}

Work reported here was funded by the Assistant Secretary for Energy Efficiency and Renewable Energy, Office of Power Technologies of the U.S. Department of Energy under Contract No. DE-ACO3-76SF00098, as well as by the American Wind Energy Association, the National Wind Coordinating Committee, and the Energy Foundation. The authors acknowledge the support and encouragement of Jack Cadogan, Tina Kaarsberg, and Larry Masueti of the U.S. Department of Energy and Randy Swisher of the American Wind Energy Association. Detailed reviews of this article were kindly provided by professors Duane Chapman and Nancy Chau of Cornell University, and by Joe Eto and Mark Bolinger of Lawrence Berkeley National Laboratory. 


\section{Introduction}

\subsection{Green Power Markets}

The introduction of customer choice in electricity markets worldwide brings with it the possibility of a green power market in which end-use customers volunteer to pay a premium for the supply of renewable electricity. ${ }^{1}$ With only a couple years of evidence to rely upon, experience with green power marketing is limited. Green marketing activity continues to grow in the United States, Europe, and Australia. But, while niche markets for green power clearly exist, few programs have exceeded 5\% penetration in the residential market. In the U.S., for example, as of mid-2000, 40\% of households had access to one or more green power products. With approximately 360,000 customers purchasing green power, an overall penetration rate of just under 1\% has been achieved (Wiser, Bolinger and Holt 2000).

Some analysts have argued that the relatively slow rate of green power uptake should come as no surprise. The high cost of marketing, unfavorable regulatory rules, the intangible nature of green power, and the prevailing lack of consumer awareness of the environmental impacts of energy production are frequently identified as barriers to adoption. Perhaps the most significant limitation to the long term success of the green market, however, is the contention that individual consumers act to maximize their own well being rather than the well being of society when making product choices. After all, when public environmental benefits are involved, the familiar economic concept of free riding would be expected to limit voluntary contributions for the betterment of the public good. If, in fact, this neoclassical-economic rationality prevails over the decision making of electricity consumers, it would appear that the green market's potential will be severely limited (Rader and Short 1998, Wiser 1998).

More optimistic observers contend that green power marketing may offer a significant opportunity for renewable energy in the long term (Nakarado 1996). After all, there is empirical evidence in other markets that suggests that consumers do not always act in their own narrow self-interest. Instead, consumers are sometimes willing to voluntarily contribute towards public environmental benefits through their own behaviors (e.g., recycling) or purchases (e.g., green consumer products). Experimental evidence also shows that individuals frequently contribute more towards public goods than predicted by traditional economic models (Andreoni 1995).

For the most part, consideration of such non-economic motivations has focused on residential households, hence motivating the current focus of many green marketers on the residential marketplace. A standard presumption of neoclassical economics is that businesses make purchase decisions based purely on economic gains and are unlikely purchasers of green power and the public environmental benefits that accrue with such purchases. Notwithstanding these

\footnotetext{
${ }^{1}$ In the United States, green power is offered to customers by regulated utilities and - in those markets open to retail competition - by competitive green marketers. Over 70 regulated utility programs are now offered in U.S., within which utility ratepayers are given the opportunity to pay more on their electricity bills to support renewable energy. Meanwhile, in the markets open to retail competition, a number of competitive marketers offer a range of renewable energy products, typically sold at a premium.
} 
claims, however, an interest in non-residential green power sales has emerged. Limited market research shows that up to $60 \%$ of businesses indicate a willingness to pay more for green power (Farhar 1999, Farhar and Houston 1996, Hoefgen 1999). More persuasively, where green power programs have targeted non-residential customers, those customers have often constituted over $20 \%$ of total green power sales (Wiser, Bolinger and Holt 2000).

\subsection{Research Objectives}

The principle purpose of this study is to explore the non-residential market for green power which encompasses business, public sector, and non-profit purchasers - through the first publicly available large-sample survey of actual non-residential green power customers in the United States. Results of the survey shed light on numerous practical issues associated with this market segment, including:

- the types of customers purchasing green power,

- how these customers made their green purchases,

- the stated reasons for selecting particular products and suppliers,

- the motivations and barriers to purchasing green power, and

- the ways green power customers derive private benefits from their purchase.

Under the assumption that non-residential customers may well represent multiple customer "segments," an additional objective of this work is to assess the effect of customer type (size, type of organization, etc.) on survey responses.

A secondary objective of this article is to frame our results in the context of academic literature on corporate environmentalism and over-compliance with environmental regulation. Voluntary environmental agreements and self-regulation are gaining increased acceptance and popularity among a variety of stakeholders. While much of the research in this area is either focused on individual case studies or is highly theoretical and abstract, there is an interesting empirical strand of the literature that explores the factors that affect the participation decisions of some of the largest firms in environmental initiatives (e.g., Arora and Cason 1996, Welch, Mazur and Bretschneider 2000, Henriques and Sadorsky 1996). By analyzing the motivations of those organizations that have voluntarily agreed to pay for green power - which consist of much smaller firms on average than those emphasized in the existing literature - we hope to contribute to this emerging literature.

\subsection{Organization of Paper}

The next section of this article reports on the survey methods used in this study and the limitations of the methods selected. The subsequent section profiles respondents to the survey, explores the green power purchasing process and barriers encountered, identifies important criteria used to select a green power supplier and product, and examines overall customer satisfaction. The discussion and analysis then turns to the motivations of customers in purchasing green power and the benefits received from those purchases, as well as to the preferences of our respondents for different forms of renewable energy support. Particular attention is paid to these latter issues, and we relate the results of this study to broader literatures in environmental 
Public Goods and Private Interests: Understanding Non-Residential Demand for Green Power

marketing and corporate environmentalism. The article closes with brief summary remarks on the implications of our analysis for the development of multiple non-residential customer segments, and we highlight the possible role of non-residential customer demand in supporting renewable electricity. 
Public Goods and Private Interests: Understanding Non-Residential Demand for Green Power 


\section{Methods}

\subsection{Survey Procedures and Sample}

Though numerous studies have explored the green power preferences and motivations of residential customers, publicly available research focusing on the non-residential market is limited (see, e.g., Holt 1997, Kalweit and Peterson 1999). To build and expand upon this existing work, we chose to implement the first large-sample mail survey of current non-residential green power customers in the United States. The target population of the survey was non-residential customers (encompassing business, public sector, and non-profit organizations) in the United States that were paying a premium for green power. This includes two population groups:

1. customers purchasing an optional green power service from a green pricing program offered by their local regulated utility, and

2. customers in restructured markets (California and Pennsylvania) purchasing a green power product from one of several competitive electricity marketers.

Our sample population was compiled with the cooperation of regulated utilities and competitive marketers offering green power products. The two largest competitive green marketers agreed to participate in our survey by providing customer contact information, as did five regulated utilities that were known to have the largest number of non-residential customer sign-ups.

Geographically, our sample is diverse, containing customers from the competitive markets of California and Pennsylvania and from regulated markets in Oregon, California, Wisconsin, and Colorado. Because of subsidies available in California, some green power products have been sold at a discount. Assuming that such subsidies are unlikely to persist indefinitely and that green power will more frequently sell at a premium, we did our best to exclude from our sample customers purchasing these products (which include approximately 40,000 non-residential customers in California).

Overall, we believe our sample population represents the larger target population reasonably well. As shown in Table 1, the entire sample population consists of 1,800 customers, each of which received the mail questionnaire in the spring of 2000. (Customers of regulated utilities received a questionnaire that differed slightly from the questionnaire distributed to customers of competitive marketers - both questionnaires are attached as Appendices A and B.) A follow-up reminder and additional copy of the questionnaire were sent to non-respondents of the initial mailing. Due to the limited follow-up procedures, we expected a low response rate. Though the $27 \%$ response rate is not high, given our sample population (business customers) and mail procedures (limited follow-up) we were pleased with this level of response and the 464 completed surveys returned. 
Table 1. Survey Response Rates

\begin{tabular}{lcccc}
\hline \hline Program Type & $\begin{array}{c}\text { Surveys } \\
\text { Mailed }\end{array}$ & $\begin{array}{c}\text { Undeliverable or } \\
\text { Bad Addresses }\end{array}$ & $\begin{array}{c}\text { Completed } \\
\text { Responses }\end{array}$ & $\begin{array}{c}\text { Response }^{\text {Rate }} \\
\text { Re }^{1}\end{array}$ \\
\hline Competitive Marketers & 1,234 & 44 & 222 & $19 \%$ \\
Regulated Utilities & 566 & 23 & 242 & $45 \%$ \\
\hline TOTAL & 1,800 & 67 & 464 & $27 \%$ \\
\hline \hline
\end{tabular}

${ }^{1}$ Calculated as: (completed responses) / (number of surveys mailed - undeliverable or bad addresses)

\subsection{Methodological Limitations}

As with any research, a number of methodological limitations challenge our ability to generalize the results of the survey. Perhaps most importantly, non-response and selection biases are expected to be especially prevalent given the low response rate to the survey, challenging our ability to generalize from our sample to the sample population much less to the overall target population. Quite possibly, those that chose to return the survey are more dedicated to the concept of green power than those who were unwilling to respond. We also acknowledge that our target population is a small one and is limited by the incipient state of the green power market. Accordingly, it is difficult to generalize the experiences of these "early adopters" to the larger potential market for green power among non-residential customers. Finally, an additional methodological challenge - which pervades all survey work - is that we must rely on the stated motivations and actions of our respondents. For a variety of reasons, responses to surveys may or may not comport with actual practice. To reduce the risk of drawing erroneous conclusions from such responses, we frequently rely on the answers to multiple questions to support our interpretations of the survey results. 


\section{Buying Green Power: Survey Results}

\subsection{Profiling the Respondents}

The profile of our respondents is as follows. As shown in Table 1, the split between customers of competitive marketers and regulated utilities is approximately equal, with $48 \%$ competitive marketer customers and $52 \%$ regulated utility customers.

The majority of the non-residential green power customers in our sample are businesses (82\%), with lesser numbers of public sector (4\%) and non-profit (14\%) organizations. For analysis purposes, we frequently combine the latter two categories, which in aggregate represent $18 \%$ of the respondents. Of those businesses responding to our survey, $82 \%$ report being primarily involved in retail sales and services compared to $18 \%$ that report being principally involved with primary industry, manufacturing, or wholesale trade.

Previous research investigating the participation of businesses in voluntary environmental programs has found that larger organizations are often more likely to volunteer (Welch, Mazur and Bretschneider 2000, Arora and Cason 1996). Based on the results from our survey, it is evident that non-residential purchasers of green power range from small organizations to some of the larger corporations in the United States. For the purposes of further analysis, we divided the respondents into three size categories:

- The "small" category, representing $57.5 \%$ of our respondents, is classified as organizations with annual revenues or budgets of less than $\$ 500,000$.

- The "medium" category spans annual revenues or budgets of $\$ 500,000$ to $\$ 10,000,000$ and contains $31.6 \%$ of respondents.

- Finally, the "large" category with over $\$ 10,000,000$ in annual revenues or budgets is represented by $10.9 \%$ of our respondents. (Though some very large institutions are included in our sample, it is important to note that many of the organizations in this largest category are still relatively small relative to, for example, typical publicly traded firms in the U.S.).

Of those respondents that were willing to share data on their electricity expenditures, a full $80 \%$ report annual electricity expenditures of less than the national average expenditure for nonresidential customers of $\$ 8,226 .^{2}$ Several respondents have sizable electricity expenditures, however, leading to a mean annual expenditure among our respondents of $\$ 88,000$, well above the national average. In general, we found that regulated utility customers were larger in terms of both annual revenue and electricity expenditures than customers of competitive marketers. ${ }^{3}$

To assess the perceptions of our respondents about the environmental predilections of their own customers (or stakeholders, in the case of non-profit and government customers), respondents were asked to estimate what percentage of their patrons made a concerted effort to buy green

\footnotetext{
2 Energy Information Administration Form EIA-861, “Annual Electric Utility Report, 1998”

${ }^{3}$ The average annual electricity expenditure was $\$ 18,700$ for customers of competitive marketers and $\$ 152,500$ for utility customers.
} 
products and services. Of our respondents, $47 \%$ state that over $20 \%$ of their customers make such a concerted effort, whereas 33\% report that they believe between $5 \%$ and $20 \%$ of the market they serve is environmentally oriented and $20 \%$ state that less than $5 \%$ of their customers make such efforts. Interestingly, there do not appear to be particularly significant differences in the responses to this question across organizational size categories or industry/organization type.

\subsection{Green Power Premiums}

The cost of green products is frequently noted as the principal barrier to their adoption. Based on our sample, it would appear that the incremental cost of green power is relatively modest.

$69 \%$ of our respondents report that green electricity is costing them more than other available options, while $24 \%$ report that it costs them about the same and $6 \%$ claim it is costing them less. As noted earlier, this last statistic suggests that our attempts to screen out those customers for whom green power is the least cost option were largely successful. A greater fraction of utility customers report green power as costing more (86\%) than marketer customers $(52 \%){ }^{4}$

The average green premium reported by non-residential customers, including those who reported receiving a discount or paying no premium, is $8.3 \% .^{5}$ Smaller organizations are found to pay higher premiums on average: the average premium paid by small organizations (defined earlier) is $9 \%$, while the average premium among large organizations is $6.4 \%$. Meanwhile, the average premium paid by the largest organizations in our sample (defined here as those with annual revenues exceeding $\$ 100$ million) is $2.6 \%$.

In aggregate, the total reported annual incremental cost of renewable energy for our respondents is $\$ 451,657$. The yearly incremental cost for small organizations averages $\$ 140$, compared to $\$ 997$ for medium organizations and \$9,030 for large organizations. Small organizations contribute only $6 \%$ of the aggregate incremental cost, compared to a $22 \%$ contribution by medium organizations and $72 \%$ for the large organizations. This last statistic shows that, while a minority of non-residential purchasers are large organizations, these customers as a group contribute significantly more than smaller firms in our sample.

\subsection{The Green Power Procurement Process}

Survey results suggest that non-residential purchasers are often initially approached by a green power provider. This is as one would expect for a new product in which customers have little if any previous experience. In aggregate, $50 \%$ of non-residential customers report that they were first approached by a provider, $24 \%$ report that they took the initiative to first approach a

\footnotetext{
${ }^{4}$ Only $2 \%$ of utility customers report that green power is costing them less than other available options, with the remaining $12 \%$ reporting that green power costs "about the same." $11 \%$ of marketer customers indicated that their green power product costs less than other options, while $37 \%$ indicated that it costs about the same.

${ }^{5}$ If weighted by total electricity expenditure, the average premium paid, (i.e., $\Sigma \$$ premiums paid monthly $/ \Sigma \$$ monthly electricity expenditures) is just over $1 \%$, influenced considerably by the presence of a few very large firms with modest green power payments.
} 
provider, and the remaining $26 \%$ state that a third party (e.g., community or environmental group) made the initial contact.

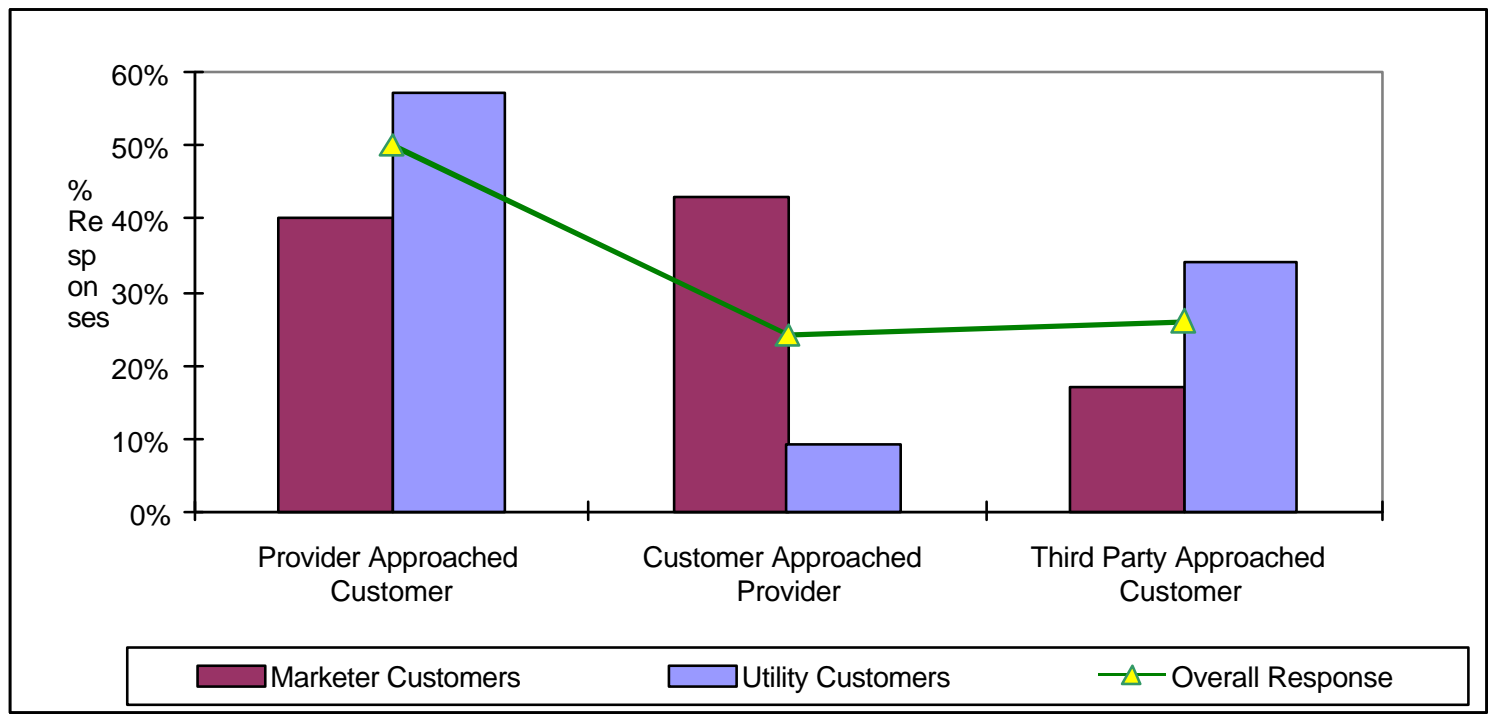

Figure 1: Who Takes the Initiative in Pursuing a Green Power Purchase?

As shown in Figure 1, regulated utilities seem to have been more successful in initiating contact with potential green customers than have competitive marketers. When controlling for customer type (i.e., marketer versus utility customer), we also find that larger organizations are somewhat less likely to initiate their green power purchase (and more likely to be approached by a green provider) than smaller organizations. This suggests that larger customers - which often represent much more sizable green power purchases overall - will generally need to be more heavily targeted by green power providers or third parties. We also find that non-profit and public-sector customers are more likely than business customers to take the initiative and make the initial approach themselves.

In general, the decision to purchase green power appears to be a quick one for most firms:

- Approximately $45 \%$ of respondents report that it took only a few days to move from initial contact with their green power provider to actually purchasing the product.

- An additional $34 \%$ state that this process took less than a month.

- $21 \%$ of respondents told us that it took them more than a month.

Though one might expect the decision process to be more time consuming for marketer customers who presumably have several products and suppliers from which to choose, this hypothesis is not supported by the data: no substantial differences are found between utility and marketer customers. Larger firms, however, were systematically more likely to spend more time in the contracting process than smaller firms (e.g., $20 \%$ of small firms versus $30 \%$ of large firms spent more than a month). 


\subsection{The Champion for Green Power}

When caring for their customer accounts, utilities have historically focused their attention on the individual within each organization responsible for energy procurement. Because the purchase of higher-cost green power is driven by different motivations than traditional electricity purchases, we hypothesized that a focus on such individuals in marketing green power could prove fruitless. To test this hypothesis, one of the survey questions asked what unit within the organization was the champion for getting the green power contract signed and implemented. Table 2 reports the results from this question.

Table 2: Champion of Green Power by Organization Size

\begin{tabular}{l|c|ccc}
\hline \hline $\begin{array}{l}\text { Organizational Unit or } \\
\text { Department }\end{array}$ & $\begin{array}{c}\text { Overall } \\
\text { Response }\end{array}$ & $\begin{array}{c}\text { Small } \\
\text { Organizations }\end{array}$ & $\begin{array}{c}\text { Medium } \\
\text { Organizations }\end{array}$ & $\begin{array}{c}\text { Large } \\
\text { Organizations }\end{array}$ \\
\hline 1. CEO, owner or director & $72.6 \%$ & $77.3 \%$ & $76.7 \%$ & $42.6 \%$ \\
2. Marketing or public relations & $5.5 \%$ & $4.8 \%$ & $6 \%$ & $4.3 \%$ \\
3. Environmental & $4.8 \%$ & $5.2 \%$ & $1.5 \%$ & $10.6 \%$ \\
4. Finance or accounting & $4.6 \%$ & $2.8 \%$ & $8.3 \%$ & $4.3 \%$ \\
5. Facilities, energy or procurement & $3.9 \%$ & $1.2 \%$ & $1.5 \%$ & $25.5 \%$ \\
6. Parent company & $0.0 \%$ & $0.0 \%$ & $0.0 \%$ & $0.0 \%$ \\
7. Other & $8.6 \%$ & $8.7 \%$ & $6 \%$ & $12.7 \%$ \\
\hline \hline
\end{tabular}

${ }^{1}$ No single type of response dominated the "other" category

Clearly, for the majority of small organizations surveyed, the CEO, owner or director was the "champion." This is not surprising, as small organizations do not often have the separate departmental units that pervade larger firms. In contrast, among larger organizations, while facilities, energy or procurement departments still play a role, CEOs/owners/directors and to a lesser extent environmental units contribute significantly to the purchase of green power.

\subsection{Green Power Selection Criteria}

Customers might use a variety of decision criteria in selecting green power suppliers and products. A better understanding of what non-residential customers are looking for can offer insights into what motivates customers to purchase green power and can help marketers refine their product design and sales approach. Accordingly, customers were asked to rate the importance of various criteria in their selection of a green power supplier and product on a 5point scale, with " 1 " being "not important" and " 5 " being "very important."

Tables 3 and 4 report the aggregated mean results and results by customer type or organizational size category. A key finding to emerge from the data presented in these tables is that customers systematically give more importance to the environmental repute of the supplier and the environmental content of the product than any other possible decision criteria. This finding suggests that the non-residential early adopters of green power represented in our sample are motivated by environmental concerns.

In particular, Table 3 shows that the socially responsible supplier criterion has the highest mean response, following by whether the supplier was easy to work with, had a good reputation, and appeared financially sound. Whether the supplier is local is of least importance overall. We also 
found that - except for the local company variable - supplier criteria were systematically viewed as less important by utility customers than by customers of competitive marketers. This is to be expected because, under a utility program, customers do not have a choice in their green power provider. Few differences in the mean rankings of selection criteria were found by customer size.

Table 3. Rating of Various Supplier Selection Criteria (mean response on 5-point scale)

\begin{tabular}{l|c|cc}
\hline \hline Supplier Selection Criteria & $\begin{array}{c}\text { Overall } \\
\text { Response }\end{array}$ & $\begin{array}{c}\text { Utility } \\
\text { Customers }\end{array}$ & $\begin{array}{c}\text { Marketer } \\
\text { Customers }\end{array}$ \\
\hline - Appears socially responsible and committed & 4.4 & 4.0 & 4.7 \\
- to the environment & & 3.7 & 3.9 \\
- Easy to work with/understands our needs & 3.7 & 3.5 & 3.8 \\
- Good reputation as supplier & 3.5 & 3.2 & 3.7 \\
- Appears financially sound & 3.4 & 3.4 & 2.3 \\
\hline
\end{tabular}

Table 4 reports the results of the product criteria. Overall, the percent of renewable energy is found to be the most important product-based selection variable, followed closely by whether the customers' premium is used to support new renewable energy facilities (rather than existing facilities) and the type of renewable energy included in the product (e.g., wind, biomass, geothermal, solar, etc). Price, often thought to be the most important of all criterion in product purchase decisions, emerges as the fourth most important criterion in this sample. Contract length and whether renewable generation is located in state are significantly less important. In general, smaller organizations appear more driven by the environmental quality criteria than larger ones, with larger organizations ranking price as being relatively more important. ${ }^{6}$ Less significant differences, therefore not shown here, were found between utility and marketer customers.

Table 4. Rating of Various Product Selection Criteria (mean response on 5-point scale)

\begin{tabular}{l|c|ccc}
\hline \hline Product Selection Criteria & $\begin{array}{c}\text { Overall } \\
\text { Response }\end{array}$ & $\begin{array}{c}\text { Small } \\
\text { Organizations }\end{array}$ & $\begin{array}{c}\text { Medium } \\
\text { Organizations }\end{array}$ & $\begin{array}{c}\text { Large } \\
\text { Organizations }\end{array}$ \\
\hline - Percent of renewable energy & 4.2 & 4.4 & 4.1 & 3.6 \\
- Focus on new renewables & 4.0 & 4.1 & 3.9 & 3.7 \\
- Type of renewable energy & 3.8 & 4.0 & 3.4 & 3.5 \\
- Price & 3.5 & 3.4 & 3.4 & 3.6 \\
- Product certified by 3 $3^{\text {rd }}$ party or & 3.3 & 3.4 & 3.2 & 3.0 \\
$\quad \begin{array}{l}\text { endorsed by environmental org. } \\
\text { - In-state renewable generation }\end{array}$ & 3.1 & 3.0 & 3.0 & 3.5 \\
- Short contract or commitment & 3.0 & 2.8 & 3.0 & 3.1 \\
$\quad$ length & & & & \\
\hline \hline
\end{tabular}

\footnotetext{
${ }^{6}$ Though the data are not shown here, we note that these trends are particularly apparent and strong among the utility customers.
} 


\subsection{Barriers to the Purchase}

Based on anecdotal evidence provided by previous case studies of some of the larger green power purchasers in restructured markets, we expected a number of barriers to complicate the purchasing process. We had heard on numerous occasions that green power providers were often unable to meet the needs of potential customers, that state regulations were thwarting real competition, that internal resistance to the purchase could be encountered within a firm, that the extra cost of green power was problematic, that information on the true environmental benefits of green power was scarce, and that some firms feared the increased scrutiny by environmental groups they might encounter after making and touting a green purchase (see, e.g., Mayer, Blank and Swezey 1999, Kasius and Seth 1998, Kalweit and Peterson 1999).

Our survey results, however, tell a very different and surprising story. We asked our respondents to rate on a 5-point scale how problematic a number of possible factors were in complicating their green power purchase ( $1=$ not at all problematic; $5=$ very problematic). As shown in Table 5 , we are forced to conclude that - among our sample at least - few respondents viewed any of the posited factors as having been formidable obstacles in their purchasing process. All of the potential factors rated between 1.2 and 2.3 on the 5-point scale. As one might expect, the extra cost of green power was rated the most significant barrier followed by incomplete information on the environmental benefits of green power, but neither was rated as particularly important overall. Apparently, difficulties with green power providers, state regulations, fear of increased scrutiny, and internal resistance were all even less problematic among our sample. ${ }^{7}$

As might be expected, given the greater complexity of a restructured market, customers of marketers viewed as somewhat more problematic incomplete information and the fact that marketers had difficulty meeting their needs. Controlling for customer type, our data also show that larger organizations encountered marginally more barriers in their purchases than smaller ones, suggesting that the larger organizations perceive the purchasing process to be more difficult in general. Neither of these differences is substantial, however.

Table 5. Barriers to Purchasing Green Power (mean response on 5-point scale)

\begin{tabular}{|c|c|c|c|}
\hline Possible Complicating Factor & $\begin{array}{c}\text { Overall } \\
\text { Response }\end{array}$ & $\begin{array}{c}\text { Utility } \\
\text { Customers }\end{array}$ & $\begin{array}{l}\text { Marketer } \\
\text { Customers }\end{array}$ \\
\hline 1. Extra cost of green power was a serious hurdle & 2.3 & 2.4 & 2.1 \\
\hline 2. Incomplete information on the environ. benefits & 1.7 & 1.6 & 1.9 \\
\hline 3. Provider had difficulty meeting our needs & 1.4 & 1.2 & 1.5 \\
\hline 4. Internal resistance by key decision makers & 1.3 & 1.3 & 1.3 \\
\hline 5. State regulations were a barrier & 1.2 & 1.2 & 1.3 \\
\hline 6. Fear of increased scrutiny by environmental groups & 1.2 & 1.2 & 1.2 \\
\hline
\end{tabular}

\footnotetext{
${ }^{7}$ Although the customers in our sample do not appear to have been hindered by these barriers, for those customers who are not today purchasing green power, real or perceived barriers could be much more problematic.
} 


\subsection{Customer Satisfaction}

Whatever the motivation of non-residential customers in selecting green power, and regardless of the barriers to those purchases, our survey respondents appear largely satisfied with their purchase and state a high likelihood of continuing their purchase. In particular, we asked our sample whether their purchase had provided the benefits that they anticipated (5-point scale; $1=$ not at all, $5=$ completely). Though only $24 \%$ state complete satisfaction, $86 \%$ of customers marked a 3 or over on this response scale. Similarly, only $2.5 \%$ of respondents indicate that they are unlikely to renew their green power purchase when the current contract or commitment ends (defined as marking 1 or 2 on the 5-point response scale; $1=$ not very likely, $5=$ very likely), compared to $87 \%$ of customers who indicate a strong likelihood of renewal (defined as marking a 4 or 5 on the response scale) 
Public Goods and Private Interests: Understanding Non-Residential Demand for Green Power 


\section{Motivations for and Benefits of the Green Power Purchase}

\subsection{Voluntary Environmental Initiatives: Why Participate?}

As noted earlier, an important objective of this study was to contribute to the contemporary literature on corporate environmentalism and the motivations of firms to exceed environmental regulations. In particular, we wished to explore the relative importance of six possible motivations for purchasing green power, an activity that we consider to be similar to other voluntary environmental initiatives that a firm might engage in.

The emerging empirical and theoretical literature on motivations to exceed environmental regulations has identified a number of explanations for this phenomenon. In particular, attention has thus far focused on four (non-exclusive) motivations (see Text Box 1 for further discussion of these possible motivations):

- efficiency gains,

- reducing the risk of future environmental regulation,

- green marketing, and

- improved public image.

This existing literature has focused principally on some of the largest firms in the U.S. economy, and the importance of each of these four motivations is premised on the belief that corporate environmentalism will only be successful if organizations believe that they will directly benefit from the resources they devote to improved environmental performance.

Because our sample included many small firms (much smaller than those typically considered in the existing literature), we hypothesized that two additional motivations - not previously emphasized in the existing literature - could prove significant:

- Employee Morale: We hypothesized that some organizations may derive value from and therefore be motivated by improving employee morale and enhancing their ability to recruit top college graduates. Though relatively little emphasis has been placed on this motivation in empirical work, improving employee morale through enhanced environmental performance has been identified in case studies and surveys as possibly an important motivator (Smith 1994, Fri 1992, Henriques and Sadorsky 1996).

- Altruism: We further hypothesized that some organizations may simply be motivated by altruism, driven by a desire to maintain their civic responsibility and a strong organizational commitment to the environment rather than by economic gain. In studies of the voluntary environmental contributions of individuals and of interest group participation more broadly, altruistic motivations are frequently mentioned as being a key motivator (e.g., Vining, Linn and Burdge 1992, Knoke 1988). There has been less attention paid, however, to the potential role of altruism in the decision making of non-residential customers generally, and businesses in particular (see, e.g., Weaver 1996). Altruism as a key motivation is dismissed by some observers of corporate environmentalism (Fri 1992) and traditional models of firm behavior assume a profit-maximizing firm that cares little for purely altruistic investments. 
Despite a dearth of empirical evidence, we suspect that admitting that altruism exists among individuals who work within organizations, but failing to consider altruism as a potential motivation for organizations themselves, is premature (Walley and Whitehead 1994). Accordingly, we view altruistic concern for the environment as worthy of empirical investigation and in need of further attention in the theoretical literature.

\section{Text Box 1 : What Motivates Firms and Institutions to Voluntarily Exceed Mandatory Environmental Standards?}

- Efficiency Gains: Industrial ecology and related literatures in corporate environmentalism stress that - in many instances - voluntary pollution reduction can be accompanied by higher resource productivity or improved product quality, particularly in an industrial or manufacturing context. In such circumstances, firms' voluntary contributions to a healthier environment may be motivated by cost minimization (e.g., Porter and van der Linde 1995, Monty 1991, Walleye and Whitehead 1994, O’Rourke, Connelly and Koshland 1996, Romm 1994, Lober 1998).

- Reducing the Risk of Future Regulation: A growing body of literature considers an organization's decision to volunteer as an attempt to pre-empt or affect the design of more stringent environmental regulation (e.g., Sergeson and Miceli 1998, Henriques and Sadorsky 1996, Barrett 1991). Under this model, firms voluntarily commit to environmental improvement with the underlying objective of either achieving reductions in regulatory scrutiny - possibly in an area unrelated to the voluntary activity - or influencing the scope of the regulations to provide competitive advantage to the firm. Accordingly, studies have found that voluntary commitments may be less likely where the threat of regulation is small and/or where the firm has greater bargaining power than the regulator (Segerson and Miceli 1998, Welch, Mazur and Bretschneider 2000).

- Green Marketing: With high levels of environmental concern among consumers and an ever increasing number of green products entering the market, an important potential motivation for voluntary environmental commitments is the desire to differentiate products based on their environmental attributes and therefore gain new customers and build the loyalty of existing ones through green marketing (Arora and Gangopadyay 1995, Ottman 1998, Kirchhoff 2000).

- Improved Public Image: Closely related to green marketing considerations are more general attempts by organizations to manage the public perception of their environmental performance (Arora and Cason 1996). While it is difficult to assign a precise monetary value to a good reputation, it is nevertheless perceived by both public and private sector organizations as being important to maintain. Perhaps the most tangible economic gains (and losses) associated with a firm's reputation have been documented by changes in capital market valuations resulting from environmental disclosures (Konar and Cohen 1997, Austin 1998, Khanna, Rose and Bojilova 1998). 


\subsection{Motivations for Green Power Purchases: Survey Results}

This study considered all six of the above possible motivations for green power purchases in an effort to determine which motivations play more important roles and how stated motivations vary with customer characteristics. Specifically, respondents were asked to indicate the importance of several different motives in influencing their organization's decision to purchase green power (5-point scale; $1=$ not important, $5=$ very important). Table 6 illustrates the wording used to distinguish possible motivations.

Table 6. Motivations for Purchasing Green Power

\begin{tabular}{ll}
\hline \hline Theoretical Motivation & Survey Description \\
\hline Efficiency Gains & Lowest Cost: Green power is our cheapest electricity option \\
\hline Public Image & $\begin{array}{l}\text { Public Image of our Organization: Maintaining a "green" public image } \\
\text { is important to us }\end{array}$ \\
\hline Green Marketing & Catering to the Environmentally-Conscious: It is important that we \\
& accommodate the needs and concerns of our customers, shareholders, \\
& or constituents \\
\hline Altruism & $\begin{array}{l}\text { 1. Organizational Values: Our organization feels a strong and } \\
\text { pervasive commitment to public health and the environment }\end{array}$ \\
& $\begin{array}{l}\text { 2. Civic Responsibility: We feel a responsibility to be community } \\
\text { leaders, not just for the environment }\end{array}$ \\
\hline Employee Morale & $\begin{array}{l}\text { Employee Morale: Employees feel more pride in an organization that } \\
\text { is giving back to the environment }\end{array}$ \\
\hline Reduced Regulatory Risk & $\begin{array}{l}\text { Reduced Risk of Future Regulation: Our voluntary actions in support } \\
\text { of renewable energy reduce the need for further government } \\
\text { intervention and regulation }\end{array}$ \\
\hline \hline
\end{tabular}

As revealed in Table 7, our results differ from the existing literature on the motivations for firms to engage in voluntary environmental initiatives. First, neither efficiency gains nor a reduction of regulatory risk are ranked highly by our respondents as important motivators. Despite the emphasis in the literature on these motivations, it is not surprising that they hold limited explanatory power among our sample. After all, green power is typically sold as a premium product - efficiency gains are therefore not relevant. Nor would the purchase of green power have an obvious influence on the fate of future regulatory action, especially for the smaller firms represented in our sample.

Table 7. Motivating Green Power Purchasers

\begin{tabular}{|c|c|c|c|c|c|c|}
\hline \multirow[b]{2}{*}{ Motivation } & \multirow[b]{2}{*}{$\begin{array}{c}\text { Mean } \\
\text { Response }\end{array}$} & \multicolumn{5}{|c|}{ Percentages } \\
\hline & & $\begin{array}{l}\text { not } \\
\text { important } \\
1\end{array}$ & 2 & 3 & 4 & $\begin{array}{r}\text { very } \\
\text { important } \\
5\end{array}$ \\
\hline - Organizational Values & 4.4 & 2 & 3 & 9 & 23 & 62 \\
\hline - Civic Responsibility & 4.1 & 6 & 5 & 16 & 24 & 49 \\
\hline - Employee Morale & 3.4 & 14 & 10 & 23 & 25 & 28 \\
\hline - Public Image & 3.2 & 21 & 11 & 22 & 22 & 25 \\
\hline - Green Marketing & 3.0 & 24 & 11 & 22 & 24 & 20 \\
\hline - Reduced Regulatory Risk & 2.6 & 38 & 13 & 17 & 15 & 17 \\
\hline - Low Cost & 2.2 & 42 & 20 & 24 & 8 & 7 \\
\hline
\end{tabular}


Second, and more interesting, are the remaining results, which suggest that altruistic factors (organizational values and civic responsibility) rank as the dominant motivations, followed by employee morale. Public image and green marketing, both viewed as potentially important motivators in the existing literature, are given secondary importance. ${ }^{8}$ The relative emphasis on altruistic motives is supported by evidence presented earlier that the criteria used to select a product and supplier often weighted more heavily towards environmental factors than pragmatic concerns of cost and convenience. The results also suggest that green power customers are acting on a blended set of personal and business motives. As discussed below, these results can, in part, be explained by the predominance of small organizations in our sample.

\subsection{Factor Analysis}

In an effort to gain insight into the more general motivational structure underlying purchasing decisions, a factor analysis of the rankings of the seven motivations was conducted using orthogonal (varimax) rotation. The results are consistent with our initial expectation that there would be two broad patterns of stated motivations to purchase green power: one encompassing more altruistic motives and a second oriented more towards private economic benefits. In particular, consistent with a preliminary correlation analysis, ${ }^{9}$ results from the factor analysis confirm that motivations are organized around two relatively unique factors which together account for $45 \%$ of the variation in all variables. ${ }^{10}$ Table 8 lists the factor loadings, communalities $^{11}$ and variance accounted for by each factor.

Table 8: Factor Loadings and Explained Variances

\begin{tabular}{lccc}
\hline \hline Motivations & Factor 1 & Factor 2 & Communality \\
\hline Lower Costs & $*$ & $*$ & .23 \\
Public Image & $*$ & .77 & .63 \\
Green Marketing & $*$ & .75 & .62 \\
Organizational Values & $\mathbf{. 7 8}$ & $*$ & .61 \\
Civic Responsibility & .72 & $*$ & .54 \\
Employee Morale & .49 & .41 & .41 \\
Reduced Regulatory Risk & $*$ & $*$ & .12 \\
\hline \multicolumn{7}{l}{ Total Variance Explained } & $22.6 \%$ & $22.5 \%$ & $45.1 \%$ \\
\hline * Only factor loadings of 0.35 or higher are reported.
\end{tabular}

\footnotetext{
${ }^{8}$ These last results are somewhat consistent with two recent studies. In the first study, only $15 \%$ of surveyed companies "strongly agreed" that "going green" would lead to increased customer loyalty (Kalweit and Peterson 1999). In the second study, several large companies indicated that even if they were to purchase all of the green power their utility had to offer, they would be unlikely to gain public relations benefits (Mayer, Blank and Swezey 1999).

${ }^{9}$ The Pearsonian correlation matrix indicates high correlation between the green marketing and public image variables $(\mathrm{r}=0.64)$ and between the civic responsibility and organizational value variables $(\mathrm{r}=0.57)$. The employee morale variable is significantly correlated with all four of these variables (with all four correlation coefficients $\geq 0.4$ ).

${ }^{10}$ If three factors are extracted, the eigenvalue of the third factor falls below 1, indicating that the appropriate number of factors to extract is 2 .

${ }^{11}$ Communalities measure the information (in terms of variance) that a variable has in common (through the common factors) with all the other variables.
} 
The "organizational values" and "civic responsibility" criteria are loaded heavily on the first factor. With the weightings so similar, we chose to represent these two criteria as a single "altruism interest" index by summing the ranks assigned to each. The second factor contains only two items with high loadings, namely public image and green marketing considerations. These two items also share a common theme: both relate to a tangible private value received by the organization. As with the first factor, because the loadings of these two criteria are so similar we later simply sum their ranks to obtain a "private benefit" index. ${ }^{12}$ Of all motivations, lower cost and regulatory risk reduction have the lowest communalities, indicating that they are not uniquely related to either factor. Employee morale loaded on both factors, suggesting that this variable contains both altruistic and private value components.

\subsection{Extracting Public Image and Green Marketing Value}

We acknowledge that the results presented above - suggesting that altruistic concerns are a dominant motivator and that private-value concerns are less prevalent, at least among the smaller firms in our sample - are subject to doubt. After all, organizations can be expected to exaggerate the importance of such altruistic concerns. To further support our findings, we therefore made an effort to compare stated motivations with reported behavior.

In particular, the survey asked whether the respondents' organizations had engaged in or had plans to engage in any of a number of activities to "get the word out" about their green power purchase, including:

1. educating the organization's employees about green energy,

2. developing point of sale marketing or public education material,

3. issuing press releases announcing the green power purchase, or

4. highlighting the purchase in reports to shareholders, members, or funding sources.

If non-altruistic concerns were principal motivators in the purchase decision, one would expect that such efforts would be commonplace. Figure 2 reveals, however, that with the exception of employee outreach, very little secondary marketing has taken place. Nor do the vast majority of respondents have any plans to greatly increase their efforts in these areas. These results certainly do not contradict the tentative conclusion that altruistic motives have been a principal driver to green power purchases thus far, followed by a desire to improve employee morale.

\footnotetext{
12 The correlation between the "altruism interest" index variable and factor 1 scores is .97 , while the "private benefit" index variable is highly correlated with factor 2 scores $(r=.96)$.
} 


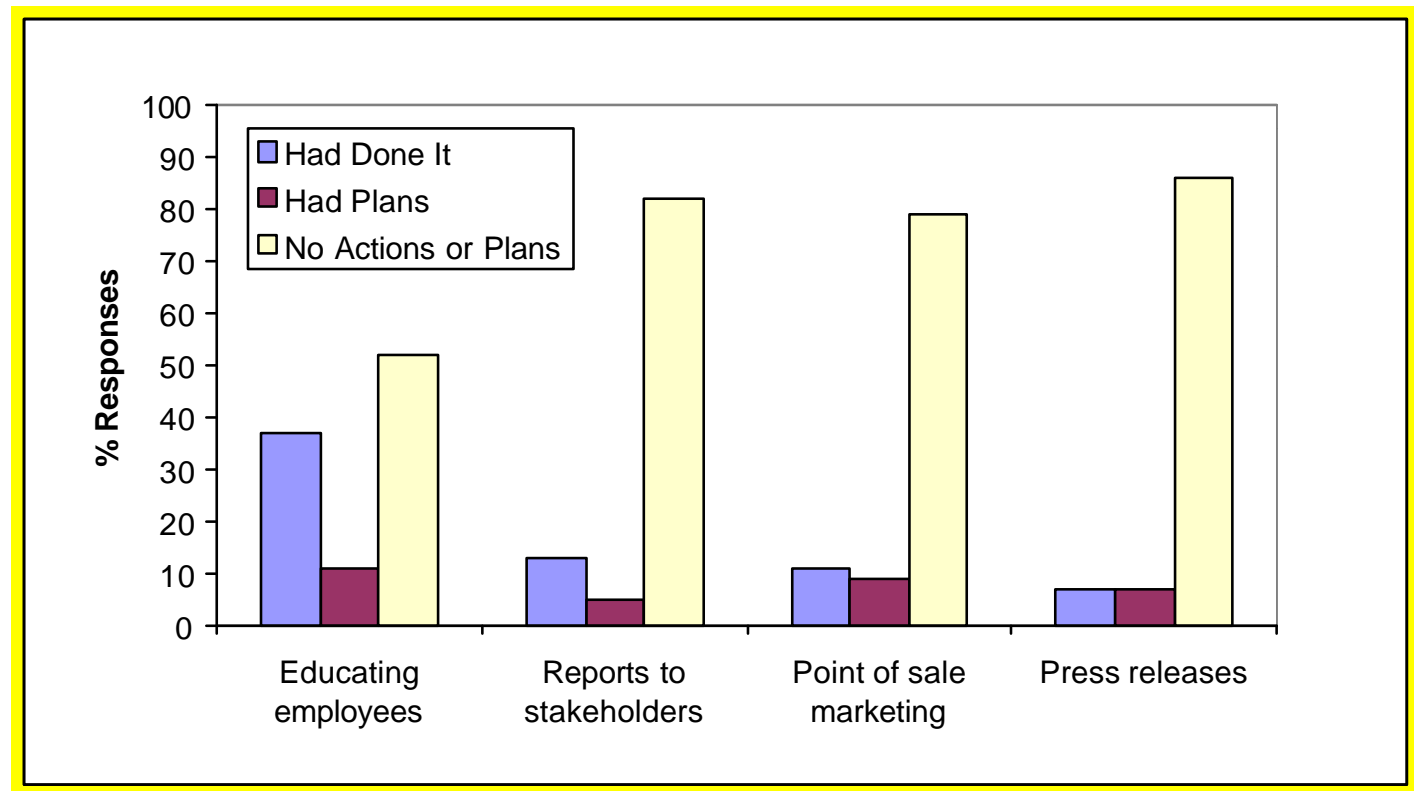

Figure 2: Getting the Word Out About Green Power

Figure 3 illustrates the relationship between: (1) the extent to which respondents were motivated by green marketing and public image considerations, and (2) the extent to which firms and organizations engaged in secondary marketing. The horizontal axis measures the "private benefits" index discussed earlier, which is simply the sum of the rankings of the green marketing and public image motivations. The vertical axis measures the degree to which organizations engaged in secondary marketing activities on an 8-point scale: 2 points for each activity already undertaken and 1 point for each planned activity. As illustrated by the figure, those organizations that rate highly on the "private benefits" index are also far more likely to have engaged in or have plans to engage in various forms of secondary marketing to capitalize on their purchase. Though not surprising, this finding demonstrates a degree of consistency between stated motivations and reported behavior. 


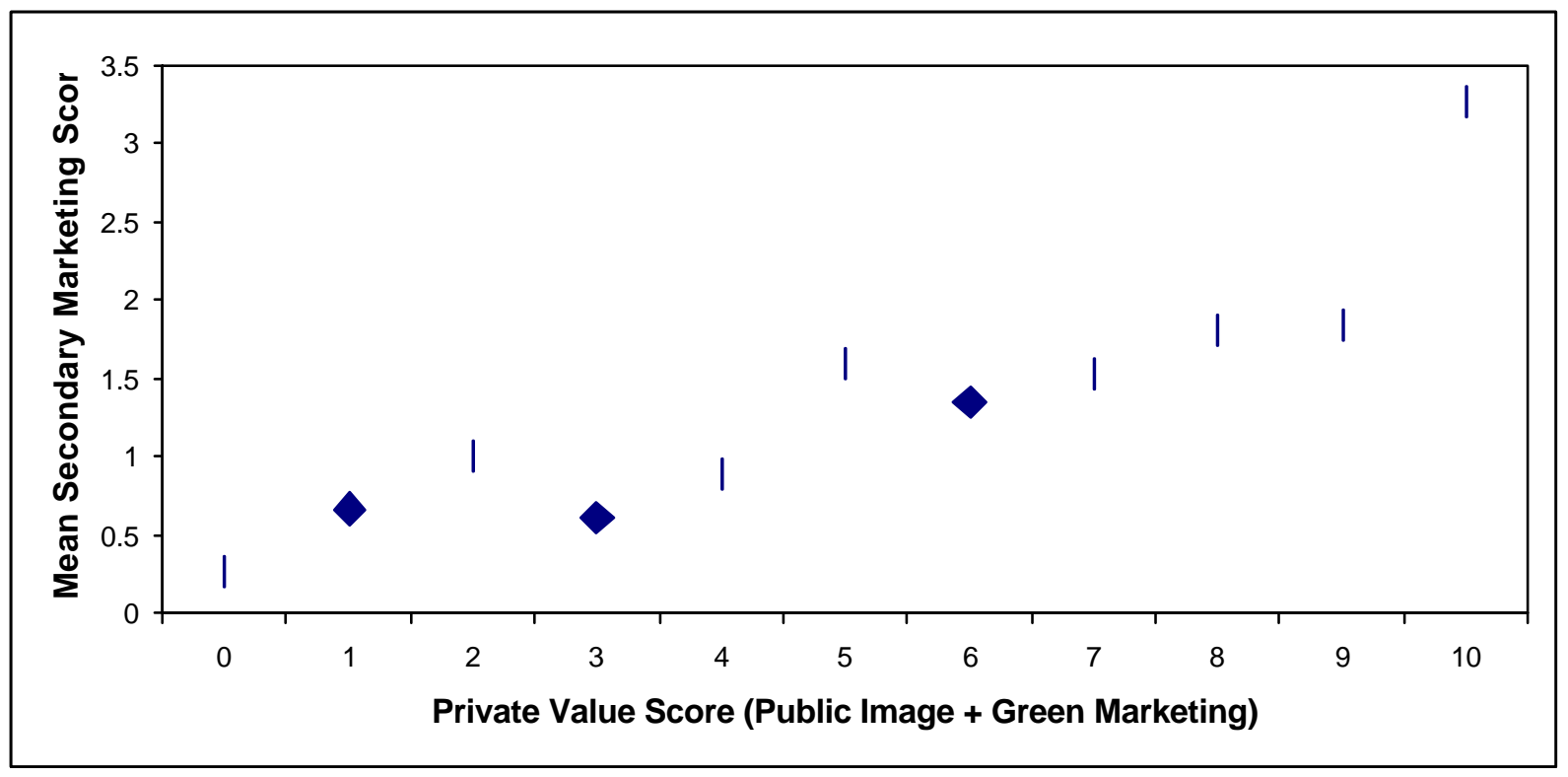

Figure 3: Secondary Marketing Efforts by Private Value Index Category

\subsection{Bandwagon and First Mover Strategies}

Extracting material value from a green power purchase may further depend on the actions of an organization's peers (Arora and Gangopadhyay 1995, Walley and Whitehead 1994). One could make a plausible argument, for example, that being among the first green purchasers would differentiate a firm and provide public relations and marketing benefits relative to a later purchase. Similarly, one might argue that once a large fraction of companies in a particular industry have switched to green power, it may be necessary for a firm to purchase a similar product to negate possible public image backlash.

As with previous research on the subject matter (Kalweit and Peterson 1999), we find somewhat conflicting evidence on such strategic use of a green purchase. In summary, while respondents seemed to downplay the importance of using green power purchases strategically, there is some indication that first mover advantages exist and, further, that once a large number of firms in an industry have taken the initiative with green power, competitors will be wise to follow suit.

In particular, we asked respondents to indicate the extent to which they agreed with a number of questions related to bandwagon and first mover incentives (5-point scale; $1=$ definitely true, $5=$ not at all true). The majority of respondents (55\%) strongly agreed that their organization's decision to purchase green power was unaffected by the activities of their peers (defined as a rating of 1 or 2 on the 5-point scale). Only $25 \%$ of respondents strongly disagreed with this statement (defined as a rating of 4 or 5). However, $40 \%$ of respondents strongly agreed that being among the first to purchase green power is an effective way for a company to set itself apart (versus $20 \%$ that strongly disagree), while $52 \%$ were in strong agreement that once a large number of their peers had purchased green power, it would become increasingly important for them to do so as well (versus $18 \%$ disagreement). Conversely, the majority (68\%) disagreed strongly with the idea that once a large number of companies in an industry had purchased green power, it would become less worthwhile for late adopters to purchase green power. 


\subsection{Regression Analysis}

The results presented thus far suggest that altruism and employee morale are the dominant motives for purchasing green power among our sample. This contrasts with much of the recent literature in corporate environmentalism, which typically posits economic rationales for participation in environmental initiatives. To better understand the difference between our findings and the existing literature, we examined the degree to which variables such as organization size and firm type could be used to discriminate between those who place a small amount and those who place a large amount of emphasis on the traditional "private benefits" motivations of public image and green marketing in green power purchasing.

Based on the factor analysis presented earlier, a linear regression model was constructed with the dependent variable a composite scale created by summing the rankings for the green marketing and improved public image motivations (the "private benefits" index, referred to earlier).

Independent variables are described in Table 9.

Table 9: Regression Variables

\begin{tabular}{|c|c|c|c|c|}
\hline Variable & "Description & Mean & Std. Dev. & "Min:Max \\
\hline \multicolumn{5}{|c|}{ Dependent Variable } \\
\hline $\begin{array}{l}\text { 1. Private Benefits } \\
\text { Motivation }\end{array}$ & $\begin{array}{l}\text { Scale constructed by summing ratings of public } \\
\text { image and green marketing motivations }\end{array}$ & 5.93 & 2.78 & $0: 10$ \\
\hline \multicolumn{5}{|c|}{ Independent Variables } \\
\hline $\begin{array}{l}\text { 1. Organization } \\
\text { Size }\end{array}$ & $\begin{array}{l}\text { Reported annual revenues or budgets of } \\
\text { organization ( } 6 \text { possible categories) }\end{array}$ & 1.81 & 1.20 & $1: 6$ \\
\hline 2. Green Clientele & $\begin{array}{l}\text { Percent of product of service sales perceived to } \\
\text { come from customers that make concerted } \\
\text { effort to purchase green products or services ( } 6 \\
\text { possible categories) }\end{array}$ & 3.96 & 1.56 & $1: 6$ \\
\hline $\begin{array}{l}\text { 3. First Mover } \\
\text { Strategy }\end{array}$ & $\begin{array}{l}\text { Agreement with: "being among the first to } \\
\text { purchase green power is an effective way for a } \\
\text { company to set itself apart" ( } 1=\text { definitely true, } \\
5=\text { not at all true) }\end{array}$ & 2.66 & 1.21 & $1: 5$ \\
\hline $\begin{array}{l}\text { 4. Dummy 1: } \\
\text { Non-Profit/ } \\
\text { Public Sector }\end{array}$ & $\begin{array}{l}\text { Dummy equals } 1 \text { if customer is a non-profit or } \\
\text { public sector organization }\end{array}$ & 0.18 & 0.38 & $0: 1$ \\
\hline $\begin{array}{l}\text { 5. Dummy 2: } \\
\text { Customer Type }\end{array}$ & $\begin{array}{l}\text { Dummy equals } 1 \text { if customer is being served } \\
\text { by a competitive marketer }\end{array}$ & 0.47 & 0.50 & $0: 1$ \\
\hline $\begin{array}{l}\text { 6. Estimated } \\
\text { Premium/ } \\
\text { Discount }\end{array}$ & $\begin{array}{l}\text { Reported premium (reported annual premium } \\
\text { paid/annual energy expenditures*100). }\end{array}$ & 8.25 & 14.3 & $-100: 104$ \\
\hline
\end{tabular}

The specific hypotheses we hoped to test through this procedure were as follows:

- Hypothesis 1: Private value motivations will be more significant among larger organizations. One might reasonably expect the "private value" driven motivations of public image and green marketing to play a stronger role among larger and potentially more bottomline oriented customers. If this were the case, then our overall finding on the importance of 
altruism as a principal motivator might be partially explained by the relatively small size of the firms in our overall sample.

- Hypothesis 2: Organizations with more environmentally conscious customers will ascribe higher importance to private value motivations. It is also plausible that those organizations that believe a higher proportion of their products or services are consumed by individuals who make a concerted effort to "buy green" will also be more able to capture private value from green power purchases and will therefore be more motivated by public image and green marketing concerns.

- Hypothesis 3: Those organizations that see strategic value in purchasing green power will be more motivated by private value interests. Firms that believe being among the first in their peer group to purchase green power is an effective way to set themselves apart are also more likely to rank private-value motivations highly.

- Hypothesis 4: For-profit companies will be more motivated by private value interests than non-profit or public institutions. Finally, we expected that those organizations that are more profit oriented will also be more concerned about marketing and public image.

We employed a "general to specific" approach in developing our preferred regression model, starting with a general model which included all independent variables that could conceivably help explain the variation in the response variable, and eliminating in a stepwise fashion those which were found to be insignificant. Although no prior hypotheses were made regarding customer type (retail versus wholesale) and green power premium variables, they remain in the reduced model because their inclusion was found to improve the explanatory power of the model. All data were standardized prior to the analysis so the relative magnitudes of the estimated regression coefficients could be more meaningfully interpreted. The results of our preferred model regression are presented in Table $10 .^{13}$

Table 10: Standardized Regression Coefficients

\begin{tabular}{lcc}
\hline \hline & \multicolumn{2}{c}{ Private Value Motivation } \\
\cline { 2 - 3 } Cariable & 0.121 & P-Value \\
\hline Intercept & 0.176 & 0.016 \\
Organization Size & 0.215 & 0.002 \\
Green Clientele & -0.218 & 0.000 \\
First Mover Strategy & 0.111 & 0.000 \\
D1: Public Sector/Non-Profit & -0.137 & 0.030 \\
D2: Customer Type & -0.108 & 0.012 \\
Premium & & 0.028 \\
\hline \hline
\end{tabular}

\footnotetext{
${ }^{13}$ To test the robustness of this model we also used the same independent variables to examine responses to the more tangible question relating to the organization's activities to "get the word out" about their purchase through press releases, secondary marketing, and the like. As the construct being tested in both models was the degree of importance ascribed to "private" value, we expected these two regressions to produce similar results. Most of the salient results of that analysis are consistent with the results presented in this article.
} 
Though the explanatory power of the resulting model is relatively low (adjusted $R^{2}=0.22$ ), the results do support several of our hypotheses.

- Perhaps most importantly, the regression results support Hypothesis 1 , with a statistically significant and positive regression coefficient for organization size. Apparently, larger firms place greater emphasis on public image and green marketing concerns when purchasing a renewable energy product than do smaller organizations. ${ }^{14}$

- Similarly, the regression results support Hypotheses 2 and 3, with significant regression coefficients for both variables, showing that organizations with higher numbers of environmentally committed customers and organizations that see strategic value in purchasing green power are more likely to ascribe importance to public image and green marketing motivations.

- The regression coefficient for the organization type variable is statistically significant but is of the opposite sign than we expected. This finding implies that private interest motivations are more important among not-for profit and public institutions than among for-profit firms. Consequently, Hypothesis 4 is not supported by this data

- Other independent variables for which we had no prior hypotheses were also found to have some significance. For example, our results show that those paying a higher premium are less likely to be motivated by private interests than those paying less for green power. Furthermore, utility customers appear to be more likely to be motivated by private benefits than their marketer customer counterparts.

\footnotetext{
${ }^{14}$ Not only is this finding plausible, but it is supported by a recent study that found altruistic concerns to be more likely to influence the decision making processes of smaller firms than their larger counterparts (Kalweit and Peterson 1999).
} 


\section{Policy Preferences}

Support for renewable energy can come from one of two sources: voluntary purchases of green power products by consumers or collective public policy measures. While voluntary approaches to environmental policy have become increasingly popular in Europe and North America, collective policy measures have historically been the principal mode of support for renewables. Contemporary policy options include the system-benefits charge (where all electricity consumers pay more for their electricity in order to raise funds to finance renewable energy projects), the renewables portfolio standard (where all utilities and power suppliers are required to include a minimum percentage of renewable energy in their supply portfolios), and further pollution taxes or regulations (where pollution from electricity generation is taxed or further regulated).

The presumption of the profit-maximizing firm implies that, in most cases, firms will disapprove of or be neutral to new environmental regulations. ${ }^{15}$ Further support for the importance of altruism in current green power purchases - and against the standard presumption of strict profitmaximization - comes from responses to a survey question that asked respondents to rate their preference for different support mechanisms, including those identified above.

If non-residential purchasers of green power were more motivated by the private marketing and image benefits than by the environmental benefits accruing to society as a whole, one would expect respondents to indicate a strong preference for voluntary approaches to supporting renewable energy. After all, private benefits can not easily be captured in the context of mandatory support.

In contrast, when asked to register their support for different ways to encourage renewable energy development, majorities of our survey respondents preferred public policy measures over voluntary consumer choice. In particular, on a 5-point scale ( $1=$ do not support, $5=$ strongly support), the renewables portfolio standard was the most strongly supported of the options with a mean response of 4.2, followed by a pollution tax (3.9) and a system-benefits charge (3.5). Among these organizations, a voluntary approach to supporting renewable generation is the least preferred alternative with a sample mean of 3.1. Among our sample of early adopters, nonresidential green power purchasers apparently acknowledge what they believe to be a limit to the effectiveness of such voluntary programs.

\footnotetext{
15 An exception to this rule occurs when, as discussed earlier, a firm believes that regulation will be created in a way that creates barriers to entry to possible competitors or otherwise provides competitive advantages to the firm.
} 
Public Goods and Private Interests: Understanding Non-Residential Demand for Green Power 


\section{Conclusions}

\subsection{Developing Customer Segments}

This study presents the first detailed look at business, non-profit, and public sector green power purchasers. From a marketing and public policy perspective, one of the key implications of this work is that there appear to be systematic differences in the procurement process, selection criteria, barriers, and motivations of non-residential green power customers that depend, in part, on a variety of customer characteristics. This suggests that customer segments might be usefully developed to assist marketers and policymakers in effectively targeting different members of the larger non-residential customer class.

Cluster analysis, a data analysis procedure designed to evaluate the prevalence and composition of specific customer segments, was unable to identify robust, non-overlapping customer segments from our data. Consequently, the results of this analysis are not presented here. Nonetheless, results presented earlier - and summarized here - do provide some insight into the differences among different types of non-residential customers.

In particular, customer size appears to have the most significant effect on survey responses. As shown in this paper, larger customers are systematically more concerned with price when selecting a product and more motivated by private interests than their smaller counterparts. Reinforcing this finding, larger organizations have consistently done more to publicize their green power purchase than smaller companies. Larger customers are also found to be less frequent initiators of their green power purchase than smaller organizations, and systematically perceive greater barriers to their purchase. This suggests that green marketers may be able to target small "mom-and-pop" businesses with a strong environmental message based on the public benefits that renewable energy provides. Targeting larger firms, on the other hand, will be more involved and will require a more refined message that emphasizes the private value of the purchase.

Though less pronounced differences in survey responses are found for other customer characteristics, customer type (whether a marketer or utility customer) also has some impact on survey responses, including the premium paid for green power, supplier criteria, and purchasing motivation. Whether a firm is primarily involved in wholesale or retail trade has only a modest impact on the majority of survey responses presented earlier, as does whether the customer is a business or fits within the non-profit and public sector category.

\subsection{Understanding Customer Motivations}

Perhaps the most interesting theoretical contribution of this research comes in its demonstration of the importance of altruism in green power purchases. This finding, and the further discovery that the principal non-altruistic motivation for purchasing green power is employee morale, differs from the existing literature on the motivations of firms to exceed environmental regulations. The existing literature focuses on motivations that are tightly linked to direct economic gain by the firm, and typically downplays the potential role of altruism (Fri 1992, Arora and Cason 1996). Our findings, however, suggest that these traditional motives are of 
lesser importance in understanding current green power purchases; instead, we find evidence that altruistic motivations extend beyond the residential market.

The findings of this paper further suggest that the discrepancy between the existing literature and our results may be driven by the size of the firms considered. In particular, our regression results find that the traditional "private benefit" motivations of public image and green marketing become stronger for larger organizations. Because the existing literature focuses principally on some of the largest firms - whereas our sample includes a majority of smaller firms - it may be that altruism is a much more influential motivator among smaller organizations that are torn by both business and personal motives. This finding is intuitively plausible. Accordingly, while the emphasis of the existing literature on private benefits may be accurate for the motivations of the largest firms in the U.S. economy, the conclusions presented in this paper suggest that those results may not be easily generalized to smaller sized firms such as those represented in our sample.

As an example, several studies have found that larger organizations are more likely to participate in voluntary environmental programs (Welch, Mazur and Bretschneider 2000, Arora and Cason 1996), perhaps because larger firms are better able to extract private value from such initiatives (larger companies may be better able to take advantage of economies of scale in environmental programs, for example, or they may be more often the target of external pressure). Conversely, when altruism is a principal motivator (as it is among our sample) one would expect that participation would peak among smaller organizations. This is consistent with a recent study that found that smaller businesses were more willing to pay a premium for cleaner energy than were larger firms (Hoefgen 1999).

The fact that altruism is a principal motivator to current non-residential green power purchases, and that purchasers are apparently receiving little material private value, also cautions against relying exclusively on voluntary demand to meet what are public environmental objectives in the development of renewable energy resources. ${ }^{16}$ The non-residential green power market is, today, a small market, and there are most certainly limits to altruism among firms. Appeals to altruism may attract early adopters of green power, but if green power is really to flourish among nonresidential customers (and especially larger customers), green power providers will need to better communicate the private rewards of the purchase. If green power purveyors are unable to credibly offer such rewards, non-residential green power demand is likely to be limited principally to smaller firms willing to give up some profits to provide a public good.

\footnotetext{
${ }^{16}$ This implication stands in contrast to Arora and Cas on (1996), who conclude that voluntary environmental initiatives may hold great promise because the largest firms with the most toxic releases are more likely to participate in a toxic reduction program.
} 


\section{References}

Andreoni, J. 1995. “Cooperation in Public-Goods Experiments: Kindness or Confusion?” The American Economic Review, 85 (4), 891-904.

Arora, S., Cason, T. 1996. "Why Do Firms Volunteer to Exceed Environmental Regulations? Understanding Participation in EPA's 33/50.” Land Economics, 72(4), 413-433.

Arora, S., Gangopadhyay, S. 1995. "Toward a Theoretical Model of Voluntary

Overcompliance.” Journal of Economic Behavior and Organization, 28 (3), 289-310.

Austin, D. 1998. "The Green and the Gold: How a Firm's Clean Quotient Affects its Value." Resources, 132, 15-17.

Barrett, S. 1991. "Environmental Regulation for Competitive Advantage." Business Strategy Review, Spring, 1-15.

Farhar, B. 1999. "Willingness to Pay for Electricity From Renewable Resources: A Review of Utility Market Research.” NREL/TP.550.26148. Golden, Colorado: National Renewable Energy Laboratory.

Farhar, B., Houston, A. 1996. "Willingness to Pay for Electricity from Renewable Energy." NREL/TP-460-21216. Golden, Colorado: National Renewable Energy Laboratory.

Fri, R. 1992. "The Corporation as a Nongovernmental Organization.” The Columbia Journal of World Business, Fall and Winter, 90-95.

Henriques, I., Sadorsky, P. 1996 “The Determinants of an Environmentally Responsible Firm: An Empirical Approach." Journal of Environmental Economics and Management, 30 (3), 381395.

Hoefgen, L. 1999. "Assessing the Commercial/Industrial Markets for On-Site Generation and Renewable Energy: Results from National Business Energy DataMart Study." Proceedings: 1999 Energy Program Evaluation Conference. Denver, Colorado.

Holt, E. 1997. "Green Power for Business: Good News from Traverse City.” Research Report \#1. Washington, D.C.: Renewable Energy Policy Project

Khanna, M., Rose, W., Bojilova, D. 1999. “Toxics Release Information: A Policy Tool for Environmental Protection" Journal of Environmental Economics and Management, 36 (3), 243 266.

Kalweit, B., Peterson, T. 1999. "Green Power Guidelines, Vol. 2: Assessing the Small and Medium Size Market Segments.” Palo Alto, California: Electric Power Research Institute. 
Kasius, A., Seth, C. 1998. "Environmental Performance through Energy Procurement in Competitive Markets." Corporate Environmental Strategy, 5(2), 75-80.

Kirchhoff, S. 2000. "Green Business and Blue Angels: A Model of Voluntary Overcompliance with Asymmetric Information.” Environmental and Resource Economics, 15, 403-420.

Knoke, D. 1988. "Incentives in Collective Action Organizations.” American Sociological Review, 53 (3), 311-329.

Konar, S., Cohen, M. 1997. "Information as Regulation: The Effect of Community Right to Know Laws on Toxic Emissions," Journal of Environmental Economics and Management, 32 (1), 109-124.

Lober, D. 1998. "Pollution Prevention as Corporate Entrepreneurship.” Journal of Organizational Change Management, 11 (2), 26-37.

Mayer, R., Blank, E., Swezey, B. 1999. “The Grassroots are Greener: A Community-Based Approach to Marketing Green Power." Research Report No. 8. Washington, D.C.: Renewable Energy Policy Project.

Monty, R. 1991. "Beyond Environmental Compliance: Business Strategies for Competitive Advantage.” Environmental Finance, 1(1), 3-11.

Nakarado, G. 1996. “ A Marketing Orientation is Key to a Sustainable Energy Future.” Energy Policy, 24(2), 187-193.

Ottman, J. 1998. Green Marketing: Opportunity for Innovation. Second Edition. Chicago, Illinois: NTC Business Books.

O’Rourke, D., Connelly, L., Koshland, C. 1996. "Industrial Ecology: A Critical Review." International Journal of Environment and Pollution, 6 (2/3), 89-112.

Porter, M., van der Linde, C. 1995. "Green and Competitive: Ending the Stalemate." Harvard Business Review, September-October, 120-134.

Rader, N., Short, W. 1998. "Competitive Retail Markets: Tenuous Ground for Renewable Energy." The Electricity Journal, 11(3), 72-80.

Romm, J. 1994. Lean and Clean Management: How to Boost Profits and Productivity by Reducing Pollution. New York, NY: Kodansha International.

Segerson, K., Miceli, T. 1998. "Voluntary Approaches to Environmental Protection: The Role of Legislative Threats." Proceedings: The Economics of Law and Voluntary Agreements in Environmental Policy. Venice, Italy.

Smith, C. 1994. "The New Corporate Philanthropy." Harvard Business Review, 72 ( 3), 105-115. 
Vining, J., Linn, N., Burdge, R. 1992. "Why Recycle? A Comparison of Recycling Motivations in Four Communities." Environmental Management, 16 (6), 785-797.

Walleye, N., Whitehead, B. 1994. "It's Not Easy Being Green.” Harvard Business Review, MayJune, 46-52.

Weaver, R. 1996. "Prosocial Behavior: Private Contributions to Agriculture's Impact on the Environment." Land Economics, 72 (2), 231-247.

Welch, E., Mazur, A., Bretschneider, S. 2000. "Voluntary Behavior by Electric Utilities: Levels of Adoption and Contribution of the Climate Challenge Program to the Reduction of Carbon Dioxide." Journal of Policy Analysis and Management, 19(3), 407-425.

Wiser, R. 1998. “Green Power Marketing: Increasing Customer Demand for Renewable Energy." Utilities Policy, 7(2), 107-119.

Wiser, R., Bolinger. M., Holt, E. 2000. "Customer Choice and Green Power Marketing: A Critical Review and Analysis of Experience to Date." Proceedings: ACEEE 2000 Summer Study on Energy Efficiency in Buildings. Pacific Grove, California. 